\title{
MENYOAL KURIKULUM 2013 DALAM SISTEM PEMBELAJARAN BERBASIS TEKNOLOGI INFORMASI GUNA MENGEMBANGKAN SOFT SKILLS DAN PENDIDIKAN KARAKTER ANAK
}

\author{
Rahmad Hidayat ${ }^{1}$ \\ ${ }^{1}$ Universitas Agama Islam Negeri Curup, Bengkulu \\ *Corresponding Address: rahmadhidayat@iaincurup.ac.id
}

Naskah diterima: 9 Desember 2021| Disetujui: 11 Desember 2021 | Diterbitkan: 13 Desember 2021

\begin{abstract}
To review the problem above, this article focuses on three problems; 1) what is the form of implementing Curriculum 2013 in an information technology-based learning system, 2) what are the factors that cause the neglect of the quality of soft skills and the value of children's character in this learning model, and 3) what are the implications? To examine the research problem above, the author will use Paulo Freire's theory of "Critical Education" to understand the pattern of teacher-student relationships in his learning model. The method used is a literature study by collecting sources from books, texts, or documents that discuss this issue. It can be concluded that the findings in this article are as follows; 1) Curriculum 2013 can still not be applied optimally in ITE-based learning, because soft skills are negated. 2) The ITE-based learning model still places students as objects and teachers as subjects, which means that in Curriculum 2013, these two relationships will be aligned. 3) The above model has implications for the decline in student character values and neglected aspects of soft skills.
\end{abstract}

Keywords: Soft Skills, Character Education, Curriculum 2013

Abstrak: Penelitian ini memiliki tiga fokus permasalahan, di antaranya 1) bagaimanakah bentuk penerapan Kurikulum 2013dalam sistem pembelajaran berbasis teknologi informasi, 2) faktor apa yang menyebabkan terabaikannya kualitas soft skill dan nilai karakter anak dalam model pembelajaran, 3) bagaimana implikasi dari permasalahan tersebut. Untuk menelaah masalah penelitian di atas, penulis akan menggunakan teori Pendidikan Kritis Paulo Frire untuk memahami pola hubungan guru dan murid dalam model pembelajarannya. Sedangkan metode yang digunakan adalah studi literatur dengan mengumpulkan sumber dari buku, teks, atau dokumen yang membahas persoalan tersebut. Dapat ditarik kesimpulan adanya temuan dalam penelitian ini, yaitu 1) Kurikulum 2013 masih tidak bisa diterapkan dengan maksimal dalam pembelajaran berbasis ITE, sebab ternegasikannya soft skill, 2) Model pembelajaran berbasis ITE masih meletakkan siswa objek dan guru sebagai subjek yang dalam Kurikulum 2013dua hubungan ini akan disejajarkan. 3) Model di atas berimplikasi pada merosotnya nilai karakter siswa dan terabaikan aspek soft skillnya.

Kata kunci: Soft Skills, Pendidikan Karakter, Kurikulum 2013 


\section{PENDAHULUAN}

Penggunaan Kurikulum 2013 dalam lembaga pendidikan memiliki tujuan untuk menyeimbangkan kualitas hard skill dan soft skill peserta didik, namun dalam sistem pembelajaran berbasis jejaring teknologi informasi, lembaga pendidikan hanya memprioritaskan aspek hard skill saja. Pengembangan potensi kepribadian siswa, interaksi sosial yang komunikatif, kejujuran, bertanggung jawab dan semua aspek soft skill siswa dalam Kurikulum 2013tidak tersentuh melalui sistem pembelajaran berbasis ICT. Penggunaan Kurikulum 2013sebagai pedoman pendidikan terbaru memang sebagai respon atas masifnya teknologi, tetapi penekanannya hanya pada materi pelajaran yang sifatnya kognitif (hard skill) siswa didik, seperti pelajaran Bahasa Indonesia (Winda, 2016). Kualifikasi guru yang dipersiapkan juga bertolak pada penguasaan teknologi informasi hanya untuk menunjang materi pelajaran pokok berbasis ICT (Rahmatina Rahim et al., 2019). Masifnya industrialisasi teknologi dapat mengancam nilai pendidikan karakter, oleh karena itulah perlu dasar pendidikan karakter yang kuat dalam sistem pendidikan di Indonesia (Agung Prihatmojo, Agustin, Ernawati, 2019). Tidak terakomodasinya aspek soft skill siswa dalam sistem pembelajaran berbasis teknologi informasi bertentangan dengan tujuan dibuatnya Kurikulum 2013.

Studi yang telah ada tentang pengemabangan soft skill dan penanaman pendidikan karakter, serta relevansinya dengan sistem pembelajaran berbasis teknologi informasi sampai sekarang masih berfokus pada tiga aspek. Pertama, studi yang membahas pengembangan karya tulis ilmiah melalui (Soft Skill) iLearning (Sukamana, 2020). Sebagaimana yang ditemukan oleh Sukamana, bahwa dosen serta mahasiswa dapat mengembangkan potensi kepenulisan karya ilmiah dan riset melalui pelatihan berbasis online untuk memperluas pengetahuannya. Kedua, penelitian yang fokus pada peran keluarga dalam mengembangkan soft skill dan karakter peserta didik (Ratnawati, 2016). Penanaman nilai karakter dan pengembangan soft skill anak didik menurut Ratnawati sangat bergantung pada lingkungan keluarga dan pengetahuan orang tua. Ketiga, studi yang mengkaji manfaat kegiatan ekstrakulikuler dalam mengembangkan soft skill dan karakter siswa (Suchaina et al., 2019). Menurut Suchaina, adanya kegiatan ekstrakulikuler dapat menunjang soft skill siswa, misalkan pentingnya mental untuk menjadi competitor bisnis di era digital. Dari penelitian yang ada belum ditemukan kajian yang membahas formulasi sistem pembelajaran berbasis ICT untuk mengimplementasikan soft skill dan pendidikan karakter anak sebagaimana tujuan dalam penggunaaan Kurikulum 2013 di lembaga pendidikan.

Tujuan dibuatnya penelitian adalah ini untuk melengkapi adanya kekurangan pada penelitian atau studi terdahulu yang tidak ditemukan perhatian khusus untuk melihat ternegasikannya aspek soft skill dalam sistem pembelajaran berbasis ICT di lembaga Pendidikan yang sampai sekarang belum 
banyak dikaji. Tujuan penting lainnya dari pembuatan penelitian ini untuk menujukkan pentingnya pendidikan karakter dan pengembangan soft skill di era revolusi industri 4.0. Oleh sebab itu, terdapat tiga riset question yang akan dijawab dalam penelitian ini, yakni (aspek deskriptif) bagaimana bentuk penerapan Kurikulum 2013 untuk mewujudkan hard skill, soft skill, dan pendidikan karakter anak didik. Masalah yang kedua akan mengkaji secara (kritis) faktor apa yang menyebabkan terabaikannya soft skill siswa dalam pembelajaran ICT berbasi jejaring internet, serta implikasi pembelajaran berbasis online terhadap merosotnya nilai pendidikan karakter.

Kajian tentang sistem pemebelajaran berbasis teknologi informasi sangat penting dilakukan karena di era revolusi industri 4.0 yang mengedepankan digitalisasi dalam aktifitas sehari-hari yang menyebabkan semua aktifitas manusia serba cepat dan praktis. Termasuk kebijakan lembaga pendidikan yang mensyaratkan semua harus berbasis jejaring internet. Akses teknologi sangat mudah didapat dan dijangkau pada era sekarang, bahkan siswa sekolah dasar menggunakan teknologi dalam pembelajaran maupun dalam interaksi di luar jam sekolah. Contoh penggunaan teknologi dalam pembelajaran seperti mencari informasi materi pelajaran tambahan lewat video pembelajaran. Sebagian besar anak sekolah dasar sudah mulai menggunakan smart phone dalam berinteraksi di luar jam sekolah, mereka menggunakannya sebagai media komunikasi dan mencari informasi. Nilai karakteristik yang harus dikembangkan oleh anak sekolah dasar di era sekarang sama halnya dengan kemampuan soft skill meliputi kemampuan mengelola diri sendiri, berkomunikasi, bertanggung jawab, jujur, dan lain sebagainya.

\section{METODE}

Dalam pengumpulan data penulis menggunakan metode studi literatur. Langkah pertama adalah mengumpulkan sumber-sumber yang merujuk pada sumber literatur dari buku-buku, elektronik, serta artikel hasil pemikiran dan hasil penelitian yang terkait dengan permasalahan-permasalahan pendidikan karakter, Soft skills, upaya yang dilakukan sekolah, serta implementasinya. Informasi yang didapatkan mengenai kajian teoritis pembiasaan soft skills siswa sejak dini dalam pencapaian tujuan pendidikan karakter dari sumber-sumber rujukan dipelajari dengan baik. Kemudian penulis malakukan penelaahan mulai dari apa itu pendidikan karakter, implementasi, soft skills apa yang harus dimiliki siswa, serta upaya yang dilakukan pendidik untuk membiasakan soft skills siswa dalam pencapaian tujuan pendidikan karakter. Hasil dari penelitian ini dipaparkan dengan tujuan agar pembaca memperoleh informasi pentingnya pembiasaan soft skills sejak dini agar anak dapat menginternalisasi nilai-nilai karakter dalam kehidupannya. 


\section{HASIL DAN PEMBAHASAN}

\section{Pendidikan Karakter}

\section{Implementasi Kurikulum 2013 pada Sekolah Dasar}

Kurikulum 2013 mengupayakan agar siswa dapat mengembangkan potensi atau bakat soft skills dan hard skills, artinya siswa tidak hanya dituntut matang dalam kompetensi keterampilan dan kompetensi pengetahuan tetapi juga matang dalam kompetensi sikap (attitude). Pada sekolah dasar, kurikulum yang digunakan adalah Kurikulum 2013. Sederhananya pemilihan Kurikulum 2013 ini memiliki kelebihan dalam muatan materi yang disajikan kepada siswa didik yang terletak pada aspek integratif, menggabungkan beberapa mata pelajaran menjadi satu tema terpadu. Dalam satu topik bahasan, pembelajaran didesain dengan integrasi ke dunia nyata dan lingkungan siswa, tujuannya agar siswa dapat belajar secara bermakna. Pembelajaran tematik terpadu memiliki keuntungan, antara lain:

a. Fleksibilitas, pembelajaran diimplmentasikan menyesuaikan dengan kemampuan dan kebutuhan siswa. Guru memahami terlebih dahulu karakteristik siswa, sebelumnya mengintegrasikan pembelajaran terpadu, kemudian guru mengaitkan materi atau konsep pembelajaran sesuai dengan lingkungan dan kemampuan siswa.

b. Menyatukan pembelajaran siswa, pembelajaran tematik terpadu menggabungkan beberapa materi kesatu topik bahasan atau sering disebut dengan tema. Dalam satu tema siswa dikenalkan dengan materi-materi yang selaras.

c. Merefleksikan dunia nyata, pembelajaran diintegrasikan dengan aktifitas siswa didik baik di dalam kelas maupun di luar kelas.

d. Selaras dengan cara anak berfikir. Anak usia sekolah dasar sudah bisa berfikir logis, rasional, objektif, dan ilmiah terhadap sesuatu yang bersifat nyata. Alur pembelajaran tematik terpadu mengarahkan anak untuk menerima, mengolah, dan merangkum menjadi satu. Hal itu sama dengan pola pikir anak usia sekolah dasar.

Kurikulum 2013 mengupayakan anak memiliki soft skills yang baik, seperti keperibadian yang baik dalam bersosial, bertanggung jawab, memiliki kejujuran yang tinggi, sikap disipli, dan lain sebagainya. Karakter yang harus dimiliki anak diimplementasikan dalam merancang perangkat pembelajaran, proses pembelajaran, dan penilaian. Contoh upaya guru dalam mengembangkan soft skills siswa dalam Kurikulum 2013 adalah sebagai berikut:

a. Merancang perangkat pembelajaran. Guru dituntut untuk membuat suatu perencanaan pembelajaran seperti silabus dan RPP yang memiliki muatan nilai dan sikap sosial di 
dalamnya. Nilai-nilai sosial yang akan dikembangkan dijelaskan dalam indikator-indikator pencapaian tujuan pembelajaran.

b. Proses pembelajaran. Pada saat proses pembelajaran, siswa diarahkan agar terbiasa dengan karakter yang santun dan sopan dalam bertanya dan menyampaikan pendapat, bertanggung jawab dan disiplin dalam tugas yang diberikan dan jujur dalam melaksanakan ujian.

c. Pemberian nilai pada rapor. Nilai rapor dalam Kurikulum 2013sudah dirancang dengan penilaian sikap spritual, nilai sikap siswa diambil dari observasi guru selama proses pembelajaran yang telah berlangsung.

Sebagaimana penjelasan dalam UU 1945 Nomor 20 Tahun 2003 Pasal 3, bahwa fungsi adanya pendidikan nasional antara lain untuk mengembangkan potensi peserta didik, membentuk watak dan karakter kebangsaan yang kuat dan beradab. Hal ini selaras denga tujuan Kurikulum 2013untuk meningkatkan kualitas pendidikan Indonesia yang selaras dengan asas atau nilai kebangsaan di dalamnya agar dapat diimplementasikan dengan maksimal.

\section{Peranan guru dalam Implementasi Kurikulum 2013}

Guru sangat berperan dalam pengimplementasian Kurikulum 2013, seperti menyusun perangkat pembelajaran berbasis Kurikulum 2013, pelaksanaan proses pembelajaran yang mengintegrasikan tujuan Kurikulum 2013, dan penilaian pada lapor Kurikulum 2013. Dalam melaksanakan peran-peran tersebut, guru terlebih dahulu mengenali karakter-karakter siswa, selanjutnya merancang dan melaksanakan pembelajaran. Anak abad 21 lebih mahir menggunakan teknologi informasi, karena mereka hidup di zaman teknologi informasi yang berkembang dengan pesat, mudah dimiliki dan diakses oleh kalangan manapun. Berikut ciri-ciri dari pembelajaran anak $\operatorname{abad} 21$ :

a. Akases untuk mendapatkan informsi dapat diperoleh dengan mudah. Guru mengusahakan agar siswa mencari bahan pembelajaran baik pengetahuan teoritis dalam kelas ataupun pengetahuan terapan yang didapatkan melalui pengalaman di luar kelas. Aktifitas pembelajaran menekankan siswa lebih pro aktif dalam mengambil infromasi sendiri, keberadaan guru lebih pada pendampingan atau supporting system saja.

b. Komputasi, anak abad 21 lebih mahir mengoperasikan mesin. Implementasi dalam pembelajaran yang dapat guru lakukan adalah mengarahkan siswa tidak hanya bisa menjawab dan menyelesaikan masalah, tetapi siswa juga bisa merumuskan masalah dalam pembelajaran.

c. Otomasi, pada abad 21 otomasi menjangkau segala pekerjaan rutin dalam kehidupan manusia sehari-hari. Implementasi dalam pembelajaran adalah mengarahkan siswa untuk 
melatih berfikir analitis atau mengambil keputusan, bukan hanya berpikir mekanistis atau prosedur rutin.

d. Komunikasi, abad 21 komunikasi bisa didapatkan dari mana saja dan bisa disebarkan kemana saja. Guru mengarahkan siswa berkerjasama dan berkolaborasi dalam berkomunikasi untuk menyelasaikan masalah dalam pembelajaran.

Anak usia sekolah dasar mimiliki rasa ingin tahu yang tinggi, mereka akan mencoba menyelidiki dan bereksperimen dengan hal yang mereka senangi, untuk itu perlunya pendampingan dari orang dewasa atau guru. Guru berperan mendampingi anak dalam memfasilitasi, memotivasi, menginsprirasi, dan menginovasi pada proses pembelajaran anak di sekolah. Guru juga memliki peran penting sebagai pendamping (Nirvani, 2018). Untuk membuat suatu perencanaan, mendampingi terapan pelaksanaan pembelajaran, maupun mengevaluasi hasil pembelajaran. Dengan adanya peran tersebut, maka dibutuhkan kualitas dan kapasitas yang baik untuk menjadi guru. Misalnya, dengan memberikan pilihan metode yang tepat agar peserta didik dapat lebih mudah memahami materi pelajaran secara menyeluruh, efektif, dan efesien. Oleh sebab itu, keberhasilan peserta didik sangat tergantung pada kualitas pengetahuan dari guru.

a. Sebagai fasilitator, peran guru dalam fasilitator sangat penting dalam proses pembelajaran. Di dalam memfasilitasi siswa guru harus berjiwa bersahabat dengan siswa atau bermitra dengan siswa, dengan demikian siswa akan merasa nyaman menyampaikan pendapat atau mengungkapkan kesulitan yang dihadapi saat proses pembelajaran berlangsung. Dalam mengembangkan karakter siswa, guru memfasilitasi lingkungan belajar yang baik, seperti berkomunikasi dengan bahasa yang santun dan sopan, disiplin dalam mengikuti proses pembelajaran, serta bersahabat dengan siswa.

b. Sebagai motivator, guru berperan sebagai pendorong dan penggerak agar siswa memiliki karakter yang baik. Contohnya, guru mengarahkan siswa agar selalu disiplin dalam mengikuti proses pembelajaran, seperti memberikan reward kepada siswa yang datang tepat waktu dan mengumpulkan tugas dengan cepat.

c. Sebagai inspirator, guru sebagai inspirator harus memiliki pengetahuan yang luas, rendah hati, dan mudah bergaul di manapun berada. Guru juga harus menunjukkan sikap yang bersahabat, memiliki keingintahuan yang kuat akan perkembangan ilmu pengetahuan dan teknologi, serta menggali dan mengembangkan bakat dari waktu ke waktu.

d. Sebagai inovator, guru berperan dalam membuat atmosfer yang menyenangkan bagi siswa dalam kelas, untuk itu dibutuhkan pembaharuan-pembaharuan mengenai metode, bahan ajar, dan media sebagai sarana belajar. Metode yang dipilih perlu penyesuaian dengan kemampuan keterampilan anak. Misalnya, untuk anak level sekolah dasar perlu strategi 
pembelajaran yang membuat peserta didik merasa senang, tidak kaku, dan membosankan. Harus ada variasi atau pembaharuan setiap pertemuan pembelajaran.

Peran guru dalam mengoptimalkan ketercapaian tujuan pendidikan karakter tidaklah mudah, namun hal itu dapat dilakukan dengan cara memperbanyak literasi dan keikutsertaan guru dalam pelatihan-pelatihan Kurikulum 2013 dan pendidikan karakter. Dengan demikian guru akan mahir mengelola kelas dalam proses pembelajaran yang terintegrasi dengan pendidikan karakter dan pengembangan soft skill siswa.

\section{Tujuan Pendidikan Karakter}

Pentingnya pendidikan karakter dalam lingkungan sekolah untuk menanamkan nilai-nilai karakter sehingga terbentuk kepribadian dan karakter yang mulia pada diri anak. Anak yang berkepribadian baik tentunya memiliki akhlak yang mulia, berprilaku baik, mudah bergaul, dan memiliki pengetahuan yang luas. Pendidikan karakter sangatlah penting untuk anak usia dini sebagai pondasi dalam mengelola emosi anak. Beberapa tujuan pokok yang perlu diketahui dalam memahami tujuan dari pendidikan karakter bangsa adalah sebagai berikut:

a. Mengembangkan potensi afektif peserta didik sebagai manusia dan warga negara yang memiliki nilai-nilai budaya dan karakter bangsa

b. Mengembangkan kebiasaan dan perilaku peserta didik yang terpuji dan sejalan dengan nilai-nilai universal dan tradisi budaya dan karakter bangsa.

c. Menanamkan jiwa kepemimpinan dan tanggung jawab peserta didik sebagai generasi penerus bangsa.

d. Mengembangkan kemampuan peserta didik menjadi manusia yang mandiri, kreatif, dan berwawasan kebangsaan.

e. Mengembangkan lingkungan kehidupan sekolah sebagai lingkungan belajar yang aman, jujur, penuh kreativitas, persahabatan, serta dengan rasa kebangsaan yang tinggi dan penuh kekuatan (Omeri, 2015).

Di era digital yang sangat pesat seperti sekarang, tidak menutup kemungkinan tersebarnya informasi budaya-budaya luar secara bebas. Penerimaan informasi dari budaya luar tentu tidak salah jika hal itu bersifat positif, menambah wawasan, dan pengetahuan. Pendidikan karakter di sekolah, mengajarkan anak agar bisa mengelola dan menyaring informasi yang bermanfaat dari pengetahuanpengetahuan yang diterima. Pengetahuan tersebut mendukung perkembangan karakter bangsa yang sejalan dengan Pancasila. Implementasi dalam pembelajaran yang dapat dilakukan guru contohnya, menampilkan video pembelajaran dengan tema "Budaya antri di negara Jepang" atau tema lain yang menginspirasi siswa dalam membangun karakter dan kepribadian yang baik. 
Mengembangkan siswa berdasarkan kehidupan sehari-hari merupakan salah satu dibentuknya pendidikan karakter anak untuk dapat menginternalisasi nilai kebudayaan dan karakter bangsa. Salah satu contoh nilai budaya Indonesia adalah gotong-royong, Pihak sekolah dapat mengimplementasikan perilaku gotong-royong kepada anak di sekolah, seperti kegiatan membersihkan lingkungan sekolah, membantu teman yang sedang tertimpa musibah, dan ikut berpartisipasi dalam kegiatan sosial di lingkungan tempat tinggal.

Karakter yang baik menentukan kesuksesan seseorang di masa mendatang, khususnya dalam hal lapangangan pekerjaan. Sebagian besar perusahaan-perusahaan mengutamakan soft skill dalam merekrut karyawan. Jadi, penanaman karakter anak sejak usia dini bermanfaat untuk kehidupan dimasa yang akan datang, anak lebih mudah mendapatkan pekerjaan sesuai dengan minat dan bakatnya jika sudah memiliki karakter yang baik.

\section{Soft Skills}

Soft skills adalah kemampuan yang harus ditanamkan pada anak sejak usia dasar, penanaman soft skills dilaksanakan di sekolah maupun di lingkungan tempat tinggal anak. Soft skills adalah keterampilan berinteraksi dengan orang lain (interpersolan skill), dan mengatur atau mengelola dirinya sendiri (intrapersonal skill) yang dapat mengembangkan etos kerja secara maksimal (Umam, Strategi Pengembangan Soft Skills pada Pemabelajaran Tematik di MIN Tanjungsari Kebumen, 2018).

\section{Soft Skills yang Harus Dimiliki Siswa SD/MI}

Soft skill yang menjadi target pencapaian adalah terampil berfikir, berkomunikasi, menemukan problem solving, kemampuan untuk survive seumur hidup, berwirausaha, memiliki etika dan moral yang bagus, profeseonal, serta memiliki jiwa leadership. Anak usia sekolah dasar diharapkan mampu berkomunkasi yang baik dan sopan dalam bergaul, tidak menggunakan kata-kata yang kasar dan merendahkan lawan berbicara (Saputra, 2020). Pengembangan soft skills anak sebaiknya diasah dan dibiasakan sedari dini agar menjadi kebiasaan yang berkelanjutan untuk masa depan anak. Berikut contoh soft skill yang harus dimiliki anak:

a. Kemampuan berkomunikasi, aktivitas penyampaian informasi tentunya diharapkan sampai kepada penerima pesan, agar pesan itu tersampaikan sebaiknya isi pesan singkat, padat, dan mudah dipahami. Dalam hal komunikasi secara langsung dibutuhkan bahasa yang sopan dan santun dalam berkomunikasi, agar proses penyampaian pesan diterima dengan baik oleh si penerima pesan. Dalam berkomunikasi siswa diajarkan dan dibimbing menggunakan bahasa yang baik dan sopan. Anak yang diajarkan berbicara yang sopan dan 
terbiasa bertutur kata yang santun akan mudah bergaul dan disenangi baik itu dilingkangan sekolah maupun lingkungan tempat tinggal.

b. Disiplin dalam mengatur waktu secara efisien. Penanaman karakter disiplin pada diri anak bisa dilakukan di rumah maupun di sekolah. Anak dibiasakan melakukan aktifitas di rumah dan di sekolah dengan disiplin, tidak mengulur-ngulur waktu dan menunda pekerjaan.

c. Kerjasama, dalam proses pembelajaran siswa diarahkan untuk belajar kelompok dalam menyelesaikan suatu permasalahan yang diberikan dan ditugaskan. Dalam kegiatan belajar kelompok, sikap kerjasama yang dikembangkan adalah saling tebuka dengan teman sekolompok, artinya bertukar pendapat dalam menemukan solusi dan menyelesaikan masalah, selain itu siswa juga belajar menghargai hasil pekerjaan anggota kelompok lainnya.

d. Jujur, siswa diharapkan memiliki karakter jujur dalam bersikap dan bertutur. Dalam proses pembelajaran, siswa senantiasa jujur dalam mengikuti proses pembelajaran. Contohnya, saat mengikuti ujian, siswa tidak boleh curang dan mencontek.

e. Tanggung jawab, orang yang memiliki sikap bertanggung jawab akan dipercaya, dihormati, dan dihargai dalam pergaulan sehari-hari. Sikap tanggung jawab sangat berperan penting sebagai bekal pergaulan anak dimasa mendatang. Hal ini perlu dikembangkan di sekolah maupun tempat tinggal siswa sedari dini. Di sekolah, siswa diajarkan untuk peduli pada kebersihan lingkungan karena menjaga kebersihan lingkungan sekolah adalah salah satu tanggung jawab siswa.

Semua atribut soft skills sangat penting untuk dikembangkan sedari dini, pengembangannya melalui penenaman nilai-nilai karakter dalam aktivitas di rumah, pada proses pembelajaran, saat jam istirahat di sekolah, serta di lingkungan tempat tinggal siswa berada. Peranan orang tua, guru, dan masyarakat sangatlah penting dalam membimbing dan menanamkan soft skills anak. Orang tua dan guru senantiasa mengawasi dan mengevaluasi aktivitas anak, agar soft skills anak yang sudah baik akan berkelanjutan dan konsisten pada diri priadi anak.

\section{Pengembangan Soft Skills dalam Pembelajaran}

Konsep yang digunakan dalam pengembangan soft skill pembelajaran sebaiknya disusun secara sistematis, mulai dari penyusunan Rencana Pelaksanaan Pembelajaran (RPP) yang berbasis pengembangan soft skill dan hard skill siswa, pelaksanaan pembelajaran yang berorientasi pada penerapan soft skill, perancangan alat evaluasi yang meningkatkan kemampuan soft skill siswa, dan tindak lanjut sebagai bahan evaluasi pencapaian tujuan pembelajaran. Pengembangan soft skill diperlukan sebuah konsep yang matang, dimulai dari persiapan pembelajaran dengan memuat RPP, 
RPP di susun dengan menyesuaikan karakteristik tema dan metode yang tepat sehingga sesuai dengan pengembangan atribut soft skill, langkah kedua pengaplikasian RPP yaitu pelaksanaan pembelajaran dan evaluasi, tahap terakhir adalah rencana tindak lanjut berdasarkan analisis kebutuhan peserta didik (Umam, 2018).

Pengembangan Soft skills dalam pembelajaran diterapkan melalui kegiatan-kegiatan pembelajaran, meliputi kegiatan pendahuluan, kegiatan inti, dan kegiatan penutup. Melalui kegiatankegiatan tersebut, diharapkan siswa terbiasa menerapkannya dalam kehidupan sehari-hari, dan menjadi sebuah kebiasaan yang berkelanjutan dan konsisten. Kemampuan berkomunikasi siswa dapat dilatih dengan mengatur intonasi saat berkomunikasi, memilih kata-kata yang santun dalam berkomunikasi, mengemukakan pendapat dan mengajukan pertanyaan jika dirasa ada materi yang sulit dipahami. Pada kegiatan diskusi atau belajar kelompok, siswa dilatih dalam kemampuan bekerja sama dengan sesama anggoa kelompok dan bertanggung jawab mencari solusi dari masalah yang disajikan, disiplin dalam menyelesaikan tugas sesuai dengan jangka waktu yang diberikan guru. Siswa juga dilatih untuk berprilaku jujur dalam mengikuti ujian, serta jujur dalam membuat tugas yang diberikan guru.

\section{Pembiasaan Soft Skills di Sekolah SD/MI}

\section{Strategi dan Kaitannya dengan Target Pencapaian Guru}

Pembelajaran tematik menghubungkan beberapa topik dari beberapa mata pelajaran untuk menemukan satu tema selanjutnya mengembangkan sub-sub tema. Menganalisis materi dari beberapa bidang studi untuk dijadikan sebuah tema, memerlukan keterampilan dan kecakapan guru dalam merencanakan pembelajaran dan mengaplikasikannya dalam proses pembelajaran. Persiapan yang harus difikirkan oleh guru dalam menyajikan pembelajaran tematik adalah memhami konteks sosial kehidupan sehari-hari menjadi topik pembelajaran. Selain itu, guru jug a perlu mempersiapkan strategi pembelajaran yang mendukung tema tersebut, karena itulah kenapa guru dianjurkan memiliki kemampuan yang tinggi dalam menyerap pengetahuan dari kehdiuapan siswa (Suhelli, 2016).

Prinsip yang perlu diperhatikan guru dalam penerapan pembelajaran tematik misalnya, (a) pembelajaran tematik bersifat terintegrasi dengan lingkungan, pemilihan topik-topik dari berbagai mata pelajaran harus dikaitkan dengan lingkungan siswa, hal ini bertujuan agar siswa memperoleh pengalaman langsung dan siswa terlatih dalam menemukan konsep; (b) pembelajaran dirancang agar siswa menemukan tema, pembelajaran diaplikasikan dengan menganalisis kebutuhan dan minat siswa terlebih dahulu selanjutnya guru membimbing siswa dalam merumuskan masalah, mencari solusi dan menyelesaikan masalah yang telah disajikan oleh guru; (c) efisiensi waktu, biaya dan tenaga. Pembelajaran dengan memadukan beberapa topik ke dalam suatu tema diharapkan capaian tujuan 
pembelajaran bisa tuntas dengan maksimal, dan siswa memperoleh pengetahuan yang luas dari berbagai materi pelajaran. Strategi yang digunakan guru dalam pembelajaran tematik adalah sebagai berikut:

a. Memilih tema, tema-tema yang digunakan dekat dengan keseharian siswa.

b. Mengorganisir tema

c. Menyiapkan sumber serta sarana pembelajaran

d. Mempersiapkan kegiatan

e. Mengimplemnetasikan materi pembelajaran

f. Slektif dalam memilih materi yang disesuaikan dengan pemaduan dan keterampilan

g. Membuat RPP yang tepat

h. merumuskan langkah-langkah kerjanya; (1) pembelajaran dirancang semenarik mungkin, siswa merasa senang dalam mengikuti pembelajaran, hal itu dilakukan dengan cara guru terkesan sebagai teman belajar bagi siswa; (2) anak dapat merasakan hasil yang bermakna dari pelajarannya, walaupun tidak dengan pelatihan paling tidak anak dapat mengalami secara langsung; (3) dan menyesuaikan kebutuhan anak (Suhelli, 2016).

Strategi pembelajaran tematik yang digunakan pada siswa sekolah dasar sangat penting mengintegrasikan nilai-nilai karakter, mulai dari merancang perangkat pembelajaran, implementasi pembelajaran, dan penilaian. Pembelajaran tematik mengintegrasikan beberapa materi ke dalam satu tema, hal tersebut menghasilkan tujuan pembelajaran yang kompleks. Untuk mengoptimalkan kinerja guru dalam pencapaian tujuan pembelajaran tersebut, dibutuhkan strategi yang baik.

Memilih tema dalam pembelajaran tematik sebaiknya strategi guru adalah mengintegrasikan tema dengan dunia nyata siswa atau yang bersentuhan dengan keseharian siswa. Anak sekolah dasar sifatnya masih senang bereksperimen, apalagi dengan hal-hal yang mereka temui ketika bermain di lingkungan tempat tinggal, pembelajaran bermakna membuat anak antusias dan termotivasi dalam mengikuti pembelajaran.

Dalam merancang perangkat pembelajaran, guru terlebih dahulu mengorganisir Kompetensi Dasar (KD) dan Standar Kompetensi (SK), kemudian menentukan indikator dan tujuan pembelajaran sesuai dengan karakter yang akan dicapai setelah siswa mempelajari materi yang diberikan. Bahan ajar dirancang sesuai denga karakteristik dan minat siswa, siswa sekolah dasar senang belajar dengan materi yang disajikan dalam bentuk gambar disertai warna. Gambar-gambar yang disajikan guru tentu terintegrasi dengan nilai-nilai karakter yang baik. Dalam hal ini dibutuhkan keterampilan guru dalam merancang bahan ajar dan media pembelajaran, guru berinovasi dalam mencompare materi dan karakter siswa. 
Penilaian di lapor siswa tidak hanya menilai kemampuan kognitif siswa, tetapi juga menilai kemampuan sosial atau soft skills dan keterampilan siswa. Kemampuan kognitif siswa bisa diambil dari nilai-nilai ulangan harian, dan ujian akhir. Nilai soft skills diambil dari hasil soft skills servasi guru selama siswa mengikuti proses velajar mengajar.

\section{Pengaruh Soft Skills terhadap Tujuan Pendidikan Karakter}

Atribut soft skills seperti kemampuan berkomunikasi, kemampuan mengelola emosi diri, integrasi kejujuran, dan disiplin diri. Semua itu selaras dan sejalan dengan tujuan pendidikan karakter. Sekolah yang memiliki soft skills baik akan mewujudkan tujuan pendidikan karakter yang maksimal. Di luar lingkungan sekolah, siswa akan mudah diterima masyarakat dalam pergaulan sehari-hari. Begitu halnya terhadap persaingan pencarian lapangan pekerjaan dimasa mendatang yang akan siswa lalui, mereka akan mudah mendapatkan lapangan pekerjaan.

Pentingnya penekanan kualitas soft skill anak akan berpengaruh pada pencapaian hards skillnya, terutama persoalan moralitas yang bagian dari serapan atas nilai-nilai spiritual keagamaan, sehingga dapat menciptakan kesadaran untuk menjadi pribadi yang memiliki akhlakul karimah serta jiwa kepemimpinannya. Dengan demikian, siswa yang mempunyai kemampuan soft skill dan kemampuan hard skills yang baik, akan menjadi pribadi yang berkualitas tinggi dengan segala potensi yang dimiliki (Nuryanto \& badaruddin, 2019),

Siswa yang mempunyai soft skills yang tinggi selalu menerapkan nilai-nilai karakter bangsa saat bergaul di lingkungan sekolah maupun di tempat tinggal, bertanggung jawab, mandiri, kreatif, jujur, dan bersahabat. Hal tersebut sejalan dengan tujuan pendidikan karakter. Dengan demikian bisa disimpulkan penerapan kemampuan soft skills yang baik di sekolah, dapat membantu mengoptimalkan pencapaian tujuan pendidikan karakter.

\section{Pembelajaran Berbasis Teknologi Informasi Prespektif Teori Pendidikan Kritis Paulo Friere}

Perkembangan tekonogi informasi dan komunikasi yang dalam istilah bahasa Inggris disingkat menjadi ICT memiliki dampak besar dalam kehidupan manusia modern. Semua hal yang berkaitan dengan aktivitas manusia saat ini mengalami transisi mekanisme dalam interaksi sosial menjadi virtual. Menurut Mohammad Zamroni dalam penelitiannya yang berjudul "Perkembangan Teknologi Komunikasi dan Dampaknya Terhadap Kehidupan" fenomena ini merupakan revolusi paradigma komunikasi sosial yang dikemabangkan menggunakan sarana canggih berupa teknologi mutaakhir. Pergesaran ini berimplikasi pada beberapa sektor, seperti politik, budaya, sosial, ekonomi, dan pendidikan yang memiliki sisi positif sekaligus negatif (Zamroni, 2009). Dalam politik akan percepatan kinerja nasional, atau dalam budaya dapat meningkatkan nasionalisme kebudayaan, 
terlebih dampak positifnya dalam peningkatan ekonomi rakyat. Pasalnya sisi negatif sering lahir dari kalangan pemuda dengan mudahnya akses untuk berjejaring sosial. Media sosial menjadi sumber informasi bagi masyarakat namun juga menjadi sarana yang sangat efektif bagi penanaman nilai-nilai yang dianggap baik (Agung Prihatmojo, Agustin, Ernawati, 2019). Terlebih dampak terhadap pendidikan sangat dirasakan signifikansinya.

Kurikulum 2013 digunakan sebagai pedoman pembelajaran yang menggantikan Kurikulum Tingkat Stauan Pendidikan (KTSP). Pemilihan Kurikulum 2013untuk diterapkan pada semua lembaga pendidikan secara nasional di bawah perguruan tinggi juga sebagai respon atas problematika aktual yang semakin ketergantungan dengan majunya teknologi. Tujuan ditetapkannya Kurikulum 2013sebagai pakem dalam pendidikan di Indoensia mengintegrasikan semua muatan materi pokok pada pengembangan teknologi informasi dan komunikasi (Wiyono, 2015). Kebermanfaatan TIK sebagai sarana pembelajaran, diantaranya; 1) mempermudah hubungan guru dan murid dan menghilangkan batas ruang jarak serta waktu, 2) memeprmudah sharing informasi dan mempercepat penyebaran ilmu pengetahuan, 3) dan sekolah virtual virtual school. Artinya, ineteraksi tatap muka akan semakin menurun intensitasnya jika pembelajarannya secara virtual dalam jaringan internet (daring). Namun, penekanan yang dalam sistem belajar berbasis teknologi informasi diharapkan guru untuk mengimplementasikan teori atau pengetahuan teoritis saja ( hard skill), sedangkan muatan soft skill hanya disisipkan pada metode atau startegi pembelajaran, dalam artian peserta didik untuk meningkatkan kualitas soft skillnya harus bersinggungan langsung dengan praktek di lapangan yang tidak akan didapatkan dalam sistem pembelajaran berbasis ITE. Terlebih dampak Covid-19 yang mengharuskan seluruh aktifitas pendidikan dilakukan secara online.

Kementerian pendidikan mengeluarkan edaran terkait "Pelaksanaan Kebijakan Pendididikan dalam Masa Darurat Penyebaran Covid-19” agar semua aktifitas pembelajaran lembaga pendidikan berbasis virtual, mulai dari Penerimaan Peserta Didik Baru (PPDB) hingga Uijian Akhir Sekolah (UAS) (Kemendikbud, 2020). Hingga saat ini, pertemuan tatap muka di sekolah antara guru dan murid untuk melakukan aktivitas pembelajaran nyaris tidak terlaksana. Sehingga guru diharuskan melakkan reformulasi sebagai bentuk responsif atas fenomena yang terjadi. Banyak pelaksanaan pembelajaran dalam jaringan "daring" berjalan tidak maksimal, mulai tidak adanya pengamatan secara intensif guru terhadap perkembangan siswa, kurangnya keseriusan dalam belajar siswa, monotonnya metode pembelajaran dengan metode dakwah, dan pemberian tugas, sehingga hanya terkesan hearing. Formulasi pembelajaran yang demikian nyaris tidak dapat menerapkan Kurikulum 2013, yang menurut Friere terjadi kesenjangan kelas dalam sekolah antara guru dan murid, bahwa murid difahami sebagai subjek passif "passive being”, dalam artian murid direduksi sebagai gelas kosong yang harus diisi pengetahuan, bukan sebagai manusia yang memiliki pengetahuan. 
Untuk memahami apakah pemililihan Kurikulum 2013berikut sistem belajar mengajar berbasis teknologi informasi dapat meningkatkan soft skill siswa dan nilai kaakternya. Jika fakta ini dikaji berdasarkan prespektif teori pendidikan kritis Paulo Freire, sistem belajar berbasis ITE/ICT masih menerapkan pendidikan ala bank. Di mana siswa didik dipahami sebagai potensi “subjek" yang dapat dieksploitasi untuk mengembangkan bisnis guru "investor" (Freire, 2003). Paradigma profit oriented ini juga mengilustrasikan sistem ITE yang menjadi sarana belajar sebagai mitra bisnis atau sister company yang juga dapat meraup keuntungan dari aplikasi atau portal yang digunakan dalam proses belajar mengajar. Selain itu, fakta yang didapatkan adalah pilihan metode pembelajaran yang direkomendasikan dalam Kurikulum 2013 agar berorientasi pada pengembangan soft skill tidak support dalam pembelajaran berbasis jaringan teknologi, hanya ada beberapa metode yang digunakan seperti dakwah, memberikan tugas, dan semua pilihan metode yang bisa diterapkan bersifat hierarki kelas. Guru lebih dominan dan otritatif dalam sistem ini, sehingga peran katif siswa didik yang snagat ditekankan dalam Kurikulum 2013untuk menyelami secara langsung dalam pengalaman sehari-hari tidak dapat terealisasikan secara maksimal. Friere menawarkan suatu metode yang mengconter adanya sistem pendidikan gaya bank dengan tawaran "problem-posing" (pendidikan hadap masalah) (Freire, 2003). Cara kerja metode ini terletak pada pembebesan secara absolute atau otentik yang sering kali disebut sebagai langkah humanisasi mengharuskan siswa atau pelajar agar menerapkan secara praktis berupa fakta kehidupan sosial kemasyarakat yang dialami dan dihadapi langsung untuk mengatasinya (Freire, 2005). Pendidkan problem solfing ini memiliki tujuan untuk meningkatkan kesadaran kognitif pada tahapan paling mendasar, yaitu menjadi subjek yang sadar. Sedangkan dalam sistem belajar yang bergantung pada teknologi informasi tidak melibatkan kesadaran siswa karena masih diposisikan sebagai objek yang perlu disadarkan atau transfer informasi.

Implikasi dari penerapan sistem ini terhadap peningkatan kualitas soft skill peserta didik dan mutu karkaternya tidak didapatkan secara signifikan. Justru peran itu didapatkan oleh lingkungan keluarga, pengetahuan orang tua, atau kegiatan ekstrakulikuler lainnya yang semuanya nyaris terdikotomi dari sistem belajar via virtual (virtual school). Sebab yang didapatkan dalam pendidikan model ini hanya fokus pada pengembangan level kognitif siswa yang diterapkan secara subjek-objek. Menurut Frire jika guru memposisikan dirinya sebagai arus sungai yang dapat membawa bebatuan di dasarnya dan murid adalah batu yang akan dibawah arus hendak kemana muara sungai itu berujung, pendidikan yang diterapkan seperti ini merupakan mentuk penindasan di dalam sekolah (Freire, 2001). 


\section{KESIMPULAN}

Tujuan diterapkannya Kurikulum 2013 pendidikan sebagai pola belajar mengajar di sekolah agar keberadaan lembaga dapat mengembangkan hard skill dan soft skill siswa yang direalisasikan dengan sarana pembelajaran berbasis teknologi informasi tidak berjalan dengan maksimal. Sistem pembelajaran berbasis teknologi ini hanya mementingkan aspek hards skill saja, serta masih meletakkan siswa sebagai objek dan guru sebagai subjek yang memiliki kewajiban transfer knowledge seperti pengetahuan akan materi pelajaran yang teoritis (kognitif). Terlebih asumsi dari para peneliti terdahulu yang meliha model pembelajaran via virtual yang dinilai dapat mempermudah akses kegiatan belajar mengajar yang selama ini terbatas jarak, waktu, dan ruang justru berpotensi terabaikannya soft skill dan karakter siswa didiknya. Karena metode yang selama ini digunakan dalam virtual school tidak semuanya cocok diperaktekkan, termasuk metode yang muatannya lebih kepada tahap analisas dan praktek.

Temuan dari hasil penelitian ini, kelebihannya terletak pada pilihan isu atau topik yang kurang diperhatikan oleh peneliti terdahulu dan telaah kritis adanya bias konsep dan rientasi dalam Kurikulum 2013 jika diterapkan dengan sistem pembelajaran berbasis tenologi dan informasi. Dengan menggunakan teori pendidikan kritis Paulo Friere dapat ditemukan adanya sistem yang masih menerapkan pendidikan ala bank, di mana siswa didik tergambarkan sebagai passive being dibandingkan guru yang cenderung dominan dalam melakukan proses pembelajaran.

Sebuah penelitian tidak lepas dari adanya kekurangan atau nilai minusnya. Dalam penelitian ini faktor itu terlihat dari adanya keterbatasan pengetahuan penulis akan ragam metode strategi yang dapat mendukung tercapainya tujuan Kurikulum 2013 jika diterapkan dalam pembelajaran berbasis teknologi informasi (virtual school). Selain itu, keterbatasan yang juga dianggap penting untuk dikoreksi adalah minimnya pengetahuan penulis akan cara kerja ICT atau ITE, sehingga tidak menutup kemungkinan adanya formulasi yang justru berpotensi mewujudkan tujuan Kurikulum 2013secara maksimal. Untuk menutupi kekurangan ini, sekaligus menjadi rekomendasi untuk peneliti yang mengkaji tema serupa dikemudian hari, diharapkan melengkapai adanya ruang-ruang keterbatasan di atas. Diharapkan untuk penelitian selanjutnya mengkaji peran lingkungan keluarga dalam pendidikan anak jika dapat kemungkinan untuk membangun kerjasama secara lebih massif dan struktur dengan lembaga sekolah. 


\section{DAFTAR PUSTAKA}

Agung Prihatmojo, Agustin, Ernawati, I. (2019). Implementasi Pendidikan Karakter di Abad 21 (Seminar Nasional Pendidikan Fakultas Ilmu Pendidikan).

Freire, P. (2001). Pendidikan Kaum Tertindas. LKiS.

Freire, P. (2003a). Pedagogy of the Oppressed. The Continuum International Publishing.

Freire, P. (2003b). Politik Pendidikan. In Nashir Budiman (Ed.), The Politics of Education. LKiS Pelangi Aksara.

Freire, P. (2005). Education for Critical Consciousness. Continum.

Kemendikbud. (2020, March 24). Kementerian Pendidikan dan Kebudayaan » Republik Indonesia. Kementerian Pendidikan Dan Kebudayaan. https://www.kemdikbud.go.id/main/blog/2020/03/mendikbud-terbitkan-se-tentangpelaksanaan-pendidikan-dalam-masa-darurat-covid19

Rahmatina Rahim, F., Stevani Suherman, D., Pengajar Jurusan Fisika, S., Universitas Negeri Padang, F., \& Pengajar Jurusan PGSD, S. (2019). Analisis Kompetensi Guru dalam Mempersiapkan Media Pembelajaran Berbasis Teknologi Informasi Era Revolusi Industri 4.0. JURNAL EKSAKTA PENDIDIKAN (JEP), 3(2), 133-141. https://doi.org/10.24036/JEP/VOL3ISS2/367

Ratnawati, D. (2016). Kontribusi Pendidikan Karakter dan Lingkungan Keluarga terhadap Soft Skill Siswa SMK. Tadris: Jurnal Keguruan Dan Ilmu Tarbiyah, 1(1), 23-32. https://doi.org/10.24042/TADRIS.V1I1.887

Suchaina, S., Kartika, D., Ayunin, K., \& Fitriyah, F. (2019). Pendampingan Ekstrakurikuler Menjahit untuk Meningkatkan Soft Skill dan Kesiapan Berwirausaha Siswa Madrasah Aliyah (MA) Sunan Ampel Keraton Pasuruan. Transformasi: Jurnal Pengabdian Masyarakat, 15(2), 115124. https://doi.org/10.20414/TRANSFORMASI.V15I2.1722

Sukamana, H. T. (2020). Prototyping ITSDI Journal Center Menggunakan Tools Invision Untuk Mewujudkan Creative Innovation Soft Skill Di Era Industri 4.0. ADI Bisnis Digital Interdisiplin Jurnal, 1(1 Juni), 56-69. https://doi.org/10.34306/ABDI.V1I1.119

Winda, N. (2016). Implementasi Kurikulum 2013dalam Pembelajaran Bahasa Indonesia Berbasis Teknologi Informasi dan Komunikasi. STILISTIKA: Jurnal Bahasa, Sastra, Dan Pengajarannya, 1(1), 87-94. https://doi.org/10.33654/sti.v1i1.343 
Wiyono, K. (2015). Pengembangan Model Pembelajaran Fisika Berbasis ICT pada Implementasi Kurikulum 2013. Jurnal Inovasi Dan Pembelajaran Fisika, 2(2), 123-131. https://doi.org/10.36706/JIPF.V2I2.2613

Zamroni, M. (2009). Perkembangan Teknologi Komunikasi dan Dampaknya Terhadap Kehidupan. Jurnal Dakwah, 10(2), 195-211. https://doi.org/10.14421/JD.2009.10205

Nirvani, H. P. (2018). Peran Guru Pendamping dalam Pembelajaran Kelas 1 di MI Ya akii Kesugihan 01 Kaupaten Cilacap. Prwokerto: IAIN Purwokerto.

Nuryanto, \& badaruddin, M. (2019). Implementasi Pendidikan Soft Skills dalam Mementuk Moralitas Siswa Madrasah. Elementary, 183-196.

Omeri, N. (2015). Pentingnya Pendidikan Karakter dalam Dunia Pendidikan. Manajer Pendidikan, 464-468.

Prihatmojo, A., Agustin, I. M., Ernawati, D., \& Indriyani, D. (2019). Implementasi Pendidikan Karakter Di Abad 21. Seminar Nasional Pendidikan Fakultas Ilmu Pendidikan (hal. 180-186). Jakarta: Universitas Muhammadiyah Jakarta.

Rachmadyanti, P. (2017). Penguatan Pendidikan Karakter bagi Siswa Sekolah Dasar Melalui Kearifan Lokal. JPSD Vol.3 No 2, 201-214.

Saputra, P. H. (2020). Peran Ekstrakurikuler dalam Meningkatkan Soft Skill Siswa SD Negeri 1 Asemrudung. Surakarta: Universitas Muhammadiyah Surakarta.

Suhelli. (2016). Strategi dalam Pencapaian Tujuan Pembelajaran Tematik pada MIN di Kota anda Aceh. Aceh: Pascasarjana UIN Ar-Raniry.

Umam, F. b. (2018). Strategi Pengembangan Soft Skill pada Pemelajaran Tematik di MIN Tanjungsari, Keumen. El-Hamra, 1-9.

Umam, F. b. (2018). Strategi Pengembangan Soft Skills pada Pemabelajaran Tematik di MIN Tanjungsari Kebumen. El-Hamra, 1-9.

Zubaedi. (2011). Desain Pendidikan Karakter: Konsep dan Aplikasinya dalam Lemaga Pendidikan. Jakarta: Kencana. 
MENYOAL KURIKULUM 2013 DALAM SISTEM PEMBELAJARAN BERBASIS TEKNOLOGI INFORMASI ...

Rahmad Hidayat 